Tohoku J. exp. Med., 1964, 82, 74-86

\title{
The Juxtaglomerular Apparatus and Aldosterone in Hyperaldosteronism
}

\author{
By \\ Tatsuo Torikai, Soitsu Fukuchi, Mitsugi Hanata, Hidenori \\ Takahashi and Hiroshi Demura
}
Department of Internal Medicine, Tohoku University School of Medicine, Sendai; Director: Prof. T. Torikai

(Received for publication, December 3, 1963)

\begin{abstract}
A correlation between the juxtaglomerular apparatus, renin or angiotensin and aldosterone was studied in various diseases with special reference to hypertensive patients and cases of secondary aldosteronism. High juxtaglomerular cell count and increased aldosterone excretion or secretion were observed in cases of hypertension due to renal artery stenosis, progressed essential hypertension and secondary aldosteronism with edema or ascites. The results suggest strongly that renin secreted from the juxtaglomerular cells or angiotensin stimulates the adrenal cortex to secrete aldosterone. It is probable that the most important factor which activates this juxtaglomerular apparatus, renin or angiotensin and aldosterone system may be a decrease of circulating blood volume. Although the causality of this system to the incidence and the maintenance of hypertension is not clear, there is no evidence that this system plays a very important role.
\end{abstract}

Tigerstedt and Bergman" found renin in crude extract of the rabbit kidney (1898). Goldblatt ${ }^{2}$ was the first to succeed in making experimental hypertension by constriction of the main renal artery of the dog (1934). In the following years the humoral mechanism of renal hypertension was elucidated by Page, Braun-Menéndez and Skeggs et al. ${ }^{3-5)}$

According to their studies renin has no vasoconstrictive effect by itself, but it is an enzyme which activates angiotonsinogen to convert into angiotensin $I$. By some another converting enzyme contained in plasma, angiotensin I changes into angiotensin II, which for the first time demonstrates a potent vasoconstriction.

On the other hand juxtaglomerular cells were first described by Ruyter $(1926)^{6}$ ). It was Goormaghtigh ${ }^{7,8)}$ who studied this apparatus in human autopsy material and concluded that juxtaglomerular cells were considered to participate in the formation of a vasopressor substance or its precursor. In recent years electron microscopy demonstrates that the granules secreted from this apparatus are specific secretory bodies, and a fluorescent study confirms the fact ${ }^{9,10}$.

鳥飼竜生, 福地総逸, 花田 貢, 高橋秀典, 出村 博 
Furthermore renin and/or angiotensin have been proved to be potent stimulants to activate the zona glomerulosa of the adrenal cortex to secrete aldosterone $e^{11-13}$. Angiotensin is now considered to be a very important factor in the regulation of aldosterone secretion.

Thus, while many studies have been done on this very interesting problem of the correlation between juxtaglomerular cells, renin and/or angiotensin and aldosterone, it is not yet perfectly clear whether this system plays a very important role in the incidence or maintenance of hypertension.

The authors also performed clinical and experimental researeh on this correlation. In the present paper our clinical data will be shown in regard to the juxtaglomerular apparatus and the urinary excretion and the secretion rate of aldosterone in patients with various diseases. We will discuss the possible significance of this system in the incidence or maintenance of hypertension and the mechanism which regulates this system.

\section{MATERIALS AND METHODS}

Both clincial and autopsy cases were selected for study.

Histopathological study for the juxtaglomerular apparatus

The materials are mostly autopsy cases as shown in Table I. After Zenkerformol fixation the renal tissues were embedded in paraffin and sections cut in $3.5 \mu$ were stained with hematoxyline-eosin, PAS and by the Bowie method ${ }^{14}$. On the PAS sections the juxtaglomerular cell count (JGCC) was calculated on 25 glomeruli according to Turgeon et al. ${ }^{15)}$ The granularity of the juxtaglomerular apparatus was also taken into consideration.

\section{Measurement of the urinary excretion and the secretion rate of aldosterone}

Clinical materials investigated were 24 normal subjects, 36 patients with essential hypertension, 15 patients with renal diseases, 12 patients with primary aldosteronism, 14 patients with secondary aldosteronism such as liver cirrhosis, congestive heart failure or metabolic edema, and 7 patients with periodic paralysis. The urinary excretion of aldosterone was estimated by a modification of Nowaczynski's method ${ }^{16)}$. In some cases the urinary excretion of free aldosterone and the aldosterone metabolite, tetrabydroaldosterone were measured in essentially the same principles as those employed by Petersan and Ulick respectively ${ }^{17,18}$. From each specific activity the aldosterone secretion rate was calculated.

\section{RESULTS}

Normal controls: The mean JGCC in 22 cases of sudden death with no remarkable macroscopical changes of the kidney was 187.7 (Fig. 1). The granules of the juxtaglomerular apparatus (JGA) were manifestly found in only 
TabLE I. JGCC in Various Diseases

\begin{tabular}{|c|c|c|c|c|c|}
\hline Disease & Material & $\begin{array}{c}\text { No. of } \\
\text { cases }\end{array}$ & $\begin{array}{l}\text { Mean heart } \\
\text { weight }\end{array}$ & $\underset{\text { weight }}{\text { Mean kidney }}$ & $\begin{array}{l}\text { Mean } \\
\text { JGCC }\end{array}$ \\
\hline Control & Autopsy & 22 & $247.7 \mathrm{~g}$ & $287.2 \mathrm{~g}$ & 187.7 \\
\hline $\begin{array}{l}\text { Goldblatt-type } \\
\text { hypertension } \\
\text { (ishcemic side) }\end{array}$ & $\begin{array}{l}\text { Autopsy } \\
\text { Operation }\end{array}$ & $\begin{array}{l}1 \\
2\end{array}$ & 290.0 & $\begin{array}{c}300.0 \\
/\end{array}$ & $\begin{array}{l}285.0 \\
272.5\end{array}$ \\
\hline $\begin{array}{l}\text { Goldblatt-type } \\
\text { hypertension(con- } \\
\text { tralateral side) }\end{array}$ & $\begin{array}{l}\text { Autopsy } \\
\text { Operation }\end{array}$ & $\begin{array}{l}1 \\
1\end{array}$ & $\begin{array}{c}290.0 \\
/\end{array}$ & $\begin{array}{c}300.0 \\
/\end{array}$ & $\begin{array}{l}155.0 \\
171.0\end{array}$ \\
\hline $\begin{array}{l}\text { Essential } \\
\text { hypertension }\end{array}$ & $\begin{array}{l}\text { Autopsy } \\
\text { Operation } \\
\text { \& biopsy }\end{array}$ & $\begin{array}{r}11 \\
4 \\
\end{array}$ & $\begin{array}{c}423.0 \\
\quad /\end{array}$ & $\begin{array}{c}262.8 \\
/\end{array}$ & $\begin{array}{l}204.4 \\
279.8\end{array}$ \\
\hline $\begin{array}{l}\text { Malignant } \\
\text { hypertension }\end{array}$ & Autopsy & 16 & 460.0 & 253.9 & 181.7 \\
\hline $\begin{array}{l}\text { Primary } \\
\text { aldosteronism }\end{array}$ & $\begin{array}{l}\text { Autopsy } \\
\text { Operation }\end{array}$ & $\begin{array}{l}1 \\
2 \\
\end{array}$ & $\begin{array}{c}\text { unknown } \\
\end{array}$ & $\begin{array}{c}\text { unknown } \\
/\end{array}$ & $\begin{array}{l}179.0 \\
189.3 \\
\end{array}$ \\
\hline $\begin{array}{l}\text { Nephrotic } \\
\text { syndrome }\end{array}$ & $\begin{array}{l}\text { Autopsy } \\
\text { Biopsy }\end{array}$ & $\begin{array}{l}4 \\
4 \\
\end{array}$ & 293.3 & $\begin{array}{c}465.0 \\
/\end{array}$ & $\begin{array}{l}207.5 \\
219.8\end{array}$ \\
\hline $\begin{array}{l}\text { Congestive } \\
\text { heart failure }\end{array}$ & Autopsy & 17 & 483.6 & 309.5 & 187.9 \\
\hline Chronic hepatitis & Autopsy & 6 & 259.5 & 298.7 & 210.0 \\
\hline Liver cirrhosis & Autopsy & 19 & 276.3 & 314.7 & 222.0 \\
\hline Hepatoma & Autopsy & 16 & 258.1 & 333.5 & 205.6 \\
\hline $\begin{array}{l}\text { Stomach ca. with } \\
\text { peritonitis carc. } \\
\text { ascites }>2,000 \mathrm{cc}\end{array}$ & Autopsy & 16 & 224.1 & 275.3 & 205.9 \\
\hline
\end{tabular}

a few cases by Bowie stain. The mean urinary excretion and the secretion rate of aldosterone in normal subjects were $2.9 \mu \mathrm{g} /$ day and $105 \mu \mathrm{g} /$ day respectively (Figs. $2 \& 3$ ).

Hypertension due to renal artery stenosis: Case 1 was a 13-year-old female. The blood pressure was $180 \mathrm{~mm} \mathrm{Hg}$ systolic, 110 diastolic. After close examination she underwent a right nephrectomy under the diagnosis of right renal artery stenosis. The JGCC of the right stenosed kindey was 250 (Fig. 5), while that of the left kindey was 171. No granules were demonstrated by Bowie stain. Before nephrectomy the secretion rate and the urinary excretion of aldosterone were $1,440 \mu \mathrm{g} /$ day and $31.2 \mu \mathrm{g} /$ day respectively. Forty days after operation the blood pressure turned to $140 / 80$, and the secretion rate and the urinary excretion of aldosterone decreased to $348 \mu \mathrm{g} /$ day and $8.3 \mu \mathrm{g} /$ day. Case 2 was a 10 -year-old male with marked stenosis of the abdominal aorta and both main renal arteries. 


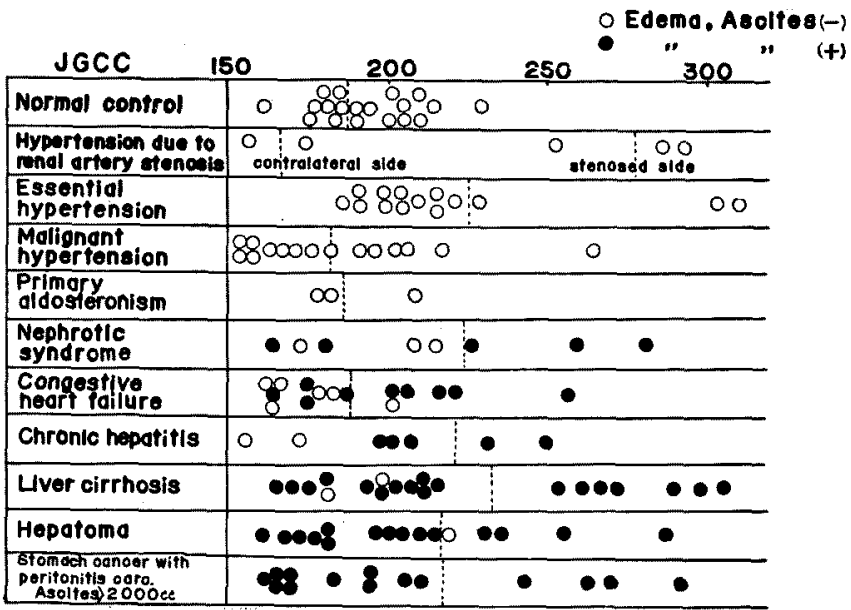

Fig. 1. JGCC in various diseases.

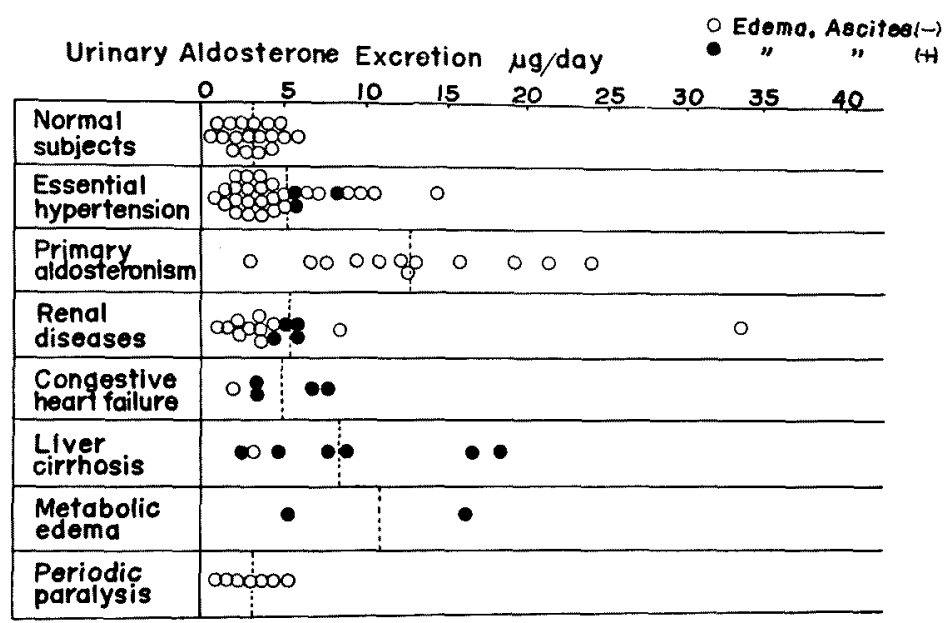

Fig. 2. Urinary aldosterone excretion in various diseases.

The blood pressure was 200/90. The secretion rate and the urinary output of aldosterone were $228 \mu \mathrm{g} /$ day and $4.9 \mu \mathrm{g} /$ day respectively. Kidney biopsy was not undertaken. Case 3 was a 23-year-old male with stensosis of the right renal artery and severe aortic arch syndrome. The blood pressure was 205 systolic, 90 diastolic. The JGCC of the right kidney by biopsy was 290. Hypergranularity was not found in the JG cells. The secretion rate of aldosterone was $96 \mu \mathrm{g} /$ day and the output $7.5 \mu \mathrm{g} /$ day. Case 4 was an autopsy of a 30 -year-old male. The blood pressure was $252 / 145$. The JGCC was 285 on the stenosed side, 155 in the contralateral kidney which showed severe malignant nephrosclerosis. Fine 


\begin{tabular}{|c|c|c|c|c|c|}
\hline \multicolumn{6}{|c|}{ Aldosterone Secretion Rate $\mu g$} \\
\hline . & & 500 & 1000 & 1500 & 2000 \\
\hline $\begin{array}{l}\text { Normal } \\
\text { subjects }\end{array}$ & 8 & & & & \\
\hline Hypertension & 8800 & $c$ & 0 & O & \\
\hline $\begin{array}{l}\text { Cushing's } \\
\text { syndrome }\end{array}$ & O & & 0 & & \\
\hline $\begin{array}{l}\text { Primary } \\
\text { aldosteronism }\end{array}$ & & & & & \\
\hline $\begin{array}{l}\text { Liver } \\
\text { cirrhosis }\end{array}$ & 00 & $\infty$ & 0 & & \\
\hline $\begin{array}{l}\text { Secondary } \\
\text { aldosteronism }\end{array}$ & oo & $0 \infty$ & Q & & $\begin{array}{l}\infty^{4200} \\
2300\end{array}$ \\
\hline $\begin{array}{l}\text { Periodic } \\
\text { paralysis }\end{array}$ & 0 & 0 & & & \\
\hline $\begin{array}{l}\text { Other } \\
\text { diseases }\end{array}$ & bo & & & & \\
\hline
\end{tabular}

Fig. 3. Aldosterone secretion rate in various diseases.

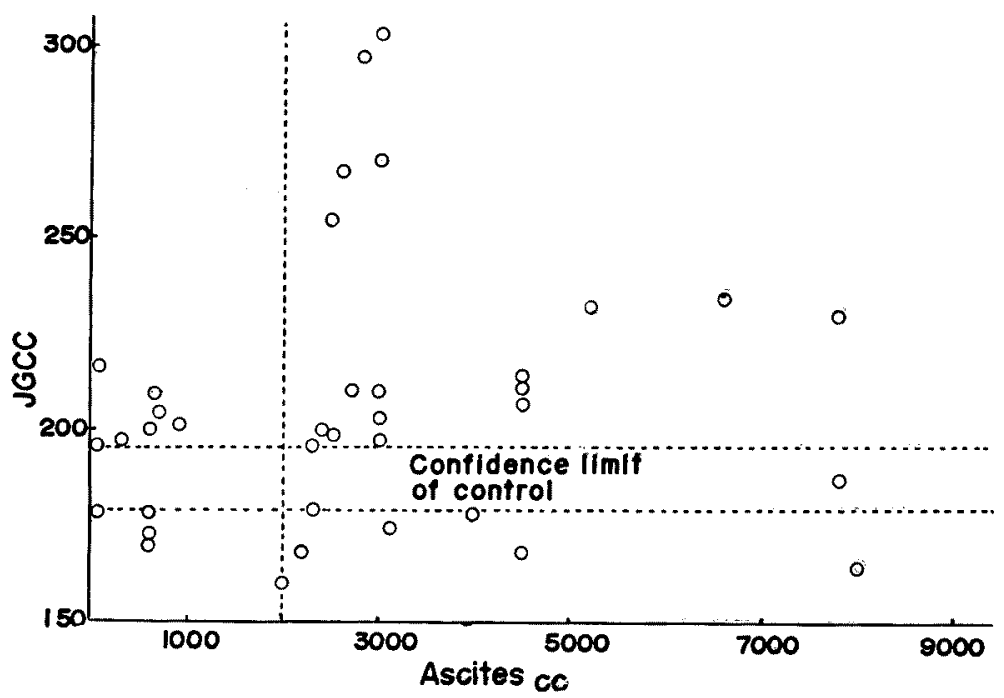

Fig. 4. The relationship between JGCC and the amount of ascites at autopsy.

granules were proved in the JGA of the stenosed kidney.

Essential hypertension: In 11 autospy cases of uncomplicated hypertension the JGCC increased moderately. Two of four biopsy cases had very high JGCC. One of them was a 39-year-old male with blood pressure of 184/120. The JGCC was 309 (Fig. 6) and the urinary aldosterone excretion was $43.7-12.0 \mu \mathrm{g} /$ day. There was nodular hyperplasia of the outer cortex of the adrenal gland. Consistent with the increase of JGCC, patients with essential hypertension had higher aldosterone excretion and secretion than normal subjects. Increase of vrinary 
aldosterone excretion was closely related to the duration or the degree of hypertension and the grade of the ocular fundi. In one ease the secretion rate of aldosterone was $852 \mu \mathrm{g} /$ day.

Malignant hypertension: Sixteen autopsy cases were available for the study of JGA. Though the glomeruli were too deteriorated to be compared with controls, the mean JGCC was slightly less than normal, 181.7. But hypergranularity of JG cells was observed in 6 cases out of 11 (Fig. 7). A patient with malignant hypertension had aldosterone secretion rate of $274 \mu \mathrm{g} /$ day.

Primary aldosteronism: The JGCC in 3 cases was within normal limit. Urinary aldosterone excretion showed a high level in 11 of 12 eases. The seeretion rate was $780 \mu \mathrm{g} /$ day in one case.

Nephrotic syndrome and other renal diseases: The JGCC in cases of nephrotic syndrome with edema or ascites was mostly high. The urinary excretion of aldosterone in patients with renal disease was also elevated especially in cases with edema or ascites. A patient with nephrotic syndrome had very high aldosterone secretion of $4,200 \mu \mathrm{g} /$ day and urinary excretion of $38.7 \mu \mathrm{g} /$ day.

Congestive heart failure: Only one of seventeen autopsy cases had a high JGCC. Aldosterone excretion was high in 2 of 5 cases. The secretion rate of aldosterone was $2,300 \mu \mathrm{g} /$ day in a patient with cor pulmonale, $632 \mu \mathrm{g} /$ day in a patient with combined valvular disease.

Liver disease: All materials studied for the JGA were autopsy cases. The JGCC tended to increase and was more than 230 in 11 of 42 cases, two of which were patients with Budd-Chiari's syndrome. In 5 of these 11 cases hypergranularity was observed in JGA by Bowie stain (Figs. 8, 9 and 10). There seemed to be a positive correlation between the JGCC and the amount of ascites at autopsy. As shown in Fig. 4, the high JGCC was seen in cases in which ascites exceeded 2,000 ce. Most of the patients with liver cirrhosis had elevated aldosterone excretion and secretion rates than normal, but the excretion of aldosterone metabolite, tetrahydroaldosterone was relatively less than that of free aldosterone.

Other various diseases: The JGCC was higher than 230 in 5 of 16 cases of peritonitis carcinomatosa with ascites more than 2,000 cc whose original site was the stomach. Patients with periodic paralysis had higher aldosterone secretion rates in spite of normal excretion.

\section{DISCUSSION}

It was Tobian ${ }^{19)}$ who described juxtaglomerular cells in experimental hypertensive rats. He observed a slight increase and a marked decrease of the juxtaglomerular gramulation index (JGI) in the clamped kidney and contralateral kidney respectively. In human material Goormaghtigh ${ }^{7,8)}$ was the first to study this apparatus and observed increase of granulation and size of juxtaglomerular cells in ischemic kidney as well as Goldblatt kidney. Recently Itskovitz et al. ${ }^{20)}$ 
observed the granularity of the juxtaglomerular cell with special reference to hypertension. But since in human kidneys JG granules are not always demonstrable as in the rats, it seems that description of granulation only through such an estimation as JGI is not enough to clarify the change of this apparatus. On this view point, Turgeon et al. ${ }^{15)}$ have employed a new counting method assaying cells of 25 juxtaglomerular apparatus. He found that in the "Goldblatttype" kidneys the JGCC increased and there was an inverse correlation between the JGCC and the duration of the hypertension before operation or the therapeutic effect of the nephrectomy. Afterwards Crocker ${ }^{21)}$ confirmed this in 25 cases of the Goldblatt kidneys. In our 4 cases of "Goldblatt-type" hypertension, the JGCC increased markedly on the stenosed sides, while on the contralateral sides of two cases the JGCC was normal in case 1, slightly increased in case 4 whose histology showed malignant nephrosclerosis. In case 1 , the blood pressure returned to normal after nephrectomy.

Some investigators observed increased aldosterone secretion rates in patients with renal artery stenosis, while the others regarded them as normal ${ }^{22}$. Sambhi et al. ${ }^{23}$ ) estimated aldosterone secretion rate in 5 hypertensive patients with demonstrable occulsive lesions of the renal arteries. It elevated moderately but less than in malignant hypertension. Cope et al. ${ }^{24)}$ found either high or low secretion rate of aldosterone in patients with renal stenosis. Carpenter et al. ${ }^{25}$ ) observed that no elevation of aldosterone secretion occurred unless the "malignant phase" supervened in experimental hypertension caused by renal artery constriction. In our three cases both the secretion rates and the urinary excretions of aldosterone showed a marked elevation in case 1, while within normal range in cases 2 and 3. But clinical finding and histology of the kidney in case 1 were not considered to be in a malignant phase yet.

As to the histological changes of the adrenal cortex in the experimental hypertension with renal artery stenosis, hypertrophy of the outer part of the cortex has been reported ${ }^{26)}$. Recently Hänze ${ }^{27)}$ described diffuse and adenomatous hypertrophy of the outer cortex in a case of pheochromocytoma with renal artery stenosis caused by the tumor and with the clinical pictures analogous to primary aldosteronism.

These findings suggest strongly that in hypertension with renal artery stenosis vasopressor substance, renin, is secreted from the JGA of the stenosed kidney to stimulate aldosterone secretion. But, on the other hand, it is known that renin is not always necessary for inducing hypertension, and hypersecretion of aldosterone is not always considered to have a primary hypertensive effect. Thus the true pathogenesis of renal hypertension remains a mystery.

In essential hypertension the JGCC increases moderately ${ }^{20}$. Turgeon found the highest count of the JGCC in cases with long clinical course conversely to that of the "Goldblatt-type" hypertension and there was no close relationship 
between the JGCC and degree of hypertension or arteriosclerosis. The JGCC in our cases of essential hypertension showed a slight increase having no definite correlation to the degree of blood pressure or duration of hypertension. These findings are consistent with the increase of renin assayed by Yoshinaga et al. ${ }^{28}$ ) in our department. On the contrary, cases of malignant hypertension had a slightly decreased JGCC conversely Turgeon's observation. But hypergranularity of JG cells was observed in a high percentage even in cases with low JGCC. Therefore both cell count and granularity seem to be necessary for the estimation of the activity of JG cells. Renin assay by Yoshinaga et al. showed in most cases a high level in patients with malignant hypertension.

Among many studies on the urinary excretion and the secretion rate of aldosterone in essential hypertension, Genest and Romanelli found them above the normal range in more than half of the cases. Venning ${ }^{31)}$ and Laragh ${ }^{32)}$ measured the urinary aldosterone excretion and aldosterone secretion rate respectively and came to the conclusion that they showed normal in uncomplicated early stage, but significantly elevated in malignant hypertension or in cases with renal disturbances. On the other hand, Cope et al. ${ }^{24}$ observed that subjects with malignant hypertension showed either high or low secretion rates of aldosterone. Sambhi et al. regarded hyperaldosteronism in the malignant phase as a secondary phenomenon. As Fukuchi, one of the authors, reported previously ${ }^{33)}$, present data revealed that increased urinary aldosterone excretions were closely related to the duration or degree of hypertension and the grade of the occular fundi. The secretion rates of aldosterone were also high in most cases of essential hypertension.

As to the adrenal glands of patients with essential hypertension, adenomatous hyperplasia is known to develop mainly in the outer part of the cortex and this hyperplasia seems to suggest high aldosterone secretion ${ }^{34,35)}$. But Sasano ${ }^{36)}$ regarded this hyperplasia as the secondary manifestations due to hypertensive artery changes of the gland.

Thus the significance of JGA, renin or angiotensin and aldosterone in the pathogenesis of essential hypertension is not clear. It seems that there is no reason to believe that they play a very important part in the incidence or development of essential hypertension.

Both urinary excretion and secretion rate of aldosterone have been found high in patients with secondary aldosteronism characterized by edema or ascites such as liver cirrhosis, nephrotic syndrome, congestive heart failure or metabolic edema $^{3738)}$. Administration of aldosterone antagonists and subtotal adrenalectomy have been noticed to be effective for the treatment of ascites or edema ${ }^{39,40}$.

The present data showed increased JGCC in such diseases as nephrotic syndrome, chronic hepatitis and hepatoma. This increase of JGCC was marked especially in cases with edema or ascites except in congestive heart failure. 
Granules of JG cells by Bowie stain were proved to be much increased in the cases with high JGCC. Corresponding to this hyperfunction of JGA, the urinary exeretion and the secretion rate of aldosterone showed definite high level in these cases. Moreover, according to Yoshinaga et al. plasma renin content was elevated in cases with odema or ascites ${ }^{28)}$.

It has been acknowledged that the increase of urinary free aldosterone with decreased tetrahydroaldosterone in liver disease is due to disturbance of the inactivation of aldosterone in liver ${ }^{41,42)}$. The authors also confirmed the fact. Wolff et al. ${ }^{37}$ ) found that in liver disease there was elevated aldosterone secretion from the adrenal glands besides metabolic disturbance. The authors ascertained this by the use of double isotope derivative method. Demura ${ }^{43)}$ investigated the adrenal glands in various liver diseases and found hyperplasia of the outer cortex mainly in liver cirrhosis. Therefore it seems probable that a chronic overproduction of renin is related to the cause of this hypertrophy of the outer cortex of the adrenal glands.

Tobian ${ }^{44)}$ suggested that the juxtaglomerular cells might be volume or stretch receptors and that conditions causing decreased stretch in the apparatus result in increased granularity and thus increased renin secretion. Decrease of circulating blood volume seems to occur by water transposition from the blood vessels to the abdominal cavity in liver cirrhosis, by water loss out of blood vessels due to serum protein lowering in nephrotic syndrome and by congestion of venous system in congestive heart failure. Present results seem to be sufficient to support his theory. Just as the increase of JGI in aminonucleoside rats had a close relation to ascites formation ${ }^{44)}$, the JGCC in liver disease was parallel to the amount of ascites at autopsy. This finding is consistent with the relationship between hyperplasia of the outer cortex of the adrenal glands and the amount of ascites reported by Demura ${ }^{43}$. The JGCC was high also in cases of stomach cancer with ascites more than 2 l. due to peritonitis carcinomatosa. Davis et al. ${ }^{45}$ ) made a stenosis of thoracic vena cava in dogs and observed a state of hyperaldosteronism coincident with inereased granularity of the juxtaglomerular cell. It is noteworthy that the authors found high JGCC and hypergranularity of JGicells in two cases of Budd-Chiari's syndrome.

From these data it may be concluded that in secondary aldosteronism renin-angiotensin-aldosterone system is markedly activated. As in primary aldosteronism both JGCC and plasma renin content were normal, elevated aldosterone secretion rate in secondary aldosteronism is a resultant of overproduction of renin or angiotensin which stimulates the zona glomerulosa of the adrenal cortex. But a recent study by Gann et al. ${ }^{46)}$ suggests that there is a factor in addition to renin or angiotensin which regulates aldosterone secretion because there was no signifioant difference in aldosterone secretion between intact and nephrectomized dogs following acute constriction of the thoracic inferior vena 
cava. Therefore it seems inadequate to conclude from present data that renin and/or angiotensin are the only factors which regulate aldosterone secretion.

\section{References}

1) Tigerstedt, R. \& Bergman, P.G., Skand. Arch. Physiol., 1898, 8, 225.

2) Goldblatt, H. et al., J. exp. Med., 1934, 59, 347.

3) Page, I.H. et al., J. exp. Med., 1940, 71, 29.

4) Braun-Menéndez, E. et al., J. Physiol., 1940, 98, 283.

5) Skeggs, L.T. et al., J. exp. Med., 1954, 99, 275.

6) Ruyter, J.N.C., Z. Zellforsch. 1925, 2, 242.

7) Goormaghtigh, N., Proc. Soc. exp. Biol,, 1945, 59, 303.

8) Goormaghtigh, N., Amer. J. Path., 1947, 23, 513.

9) Hartroft, P.M. \& Newmark, L.N., Anat. Rec. 1961, 139, 185.

10) Edelman, R. \& Hartroft, P.M., Circulation Res., 1961, 9, 1069.

11) Gross, F., Klin. Wschr., 1958, 36, 693.

12) Genest, J. et al., Circulation Res. 1961, 9, 792.

13) Laragh, J.H. et al., J. Amer. med. Ass., 1960, 171, 234.

14) Pitcock, J.A. \& Hartroft, P.M., Amer, J. Path., 1958, 34, 863.

15) Turgeon, C. \& Sommers, S.C., Amer. J. Path., 1961, 38, 227.

16) Nowaczynski, W. et al., Canad. J. Biochem. 1957, 35, 425.

17) Kliman, B. \& Peterson, R.E., J. biol. Chem., 1960, 235, 1639.

18) Ulick, S. et al., Trans. Ass. Amer. Phycns, 1958, 71, 225.

19) Tobian, L. et al., J. clin. Invest., 1958, 37, 660.

20) Itskovitz, E.A. et al., Ann. intern. Med., 1963, 59, 8.

21) Crocker, D.W. et al. New Engl. J. Med., 1962, 267, 794.

22) Goldberg, M. \& McCurdy, D.K., Ann. intern. Med., 1963, 59, 24.

23) Sambhi, M.P. et al., Metabolism, 1963, 12, 498.

24) Cope, C.L. et al., Brit. med. J., 1962, No. 5279, 659.

25) Carpenter, C.J. et al., J. clin. Invest., 1961, 40, 2026.

26) Pasqualino, A. \& Bourne, G.H., Nature, 1958, 182, 1426.

27) Hänze, S.A. et al., Klin. Wschr., 1963, 41, 219.

28) Yoshinaga, K. et al., Tohoku J. Exper. Med., 1953, 80, 32.

29) Genest, J. et al., Proc. Soc. exp. Biol. 1958, 97, 676.

30) Romanelli, R. et al., J. clin. Invest, 1961, 40, 338.

31) Venning, E.H. et al., Circulation, 1961, 23, 168.

32) Laragh, J.H., Ann. intern. Med., 1960, 53, 259.

33) Fukuchi, S., Folia Endocrinologica Japonica, 1960, 36, 1371.

34) Sasano, N., Tohoku J. exp. Med., 1961, 73, 363.

35) Wilens, S.L. \& Plair, C.M., Amer. J. Path., 1962, 41, 225.

36) Sasano, N. et al., The Saishin-Igaku (Jap.), 1963, 18, 1728.

37) Wolff, H.P. et al., Klin. Wschr., 1956, 34, 366.

38) Stormont, J.M. et al, J. Lab. clin. Med., 1959, 53, 396.

39) Giuseffe, J. et al., New Engl. J. Med., 1957, 257, 796.

40) Bartter, F.C., The Clinical Use of Aldosterlone Antagonists, 1960, Charles C. Thomas, Springfiled.

41) Chart, J.J. et al., J. clin. Invest., 1956, 35, 254.

42) Gordon, E.S., J. Lab. clin. Med., 1954, 44, 803.

43) Demura, H., Tohoku J. exp. Med., 1962, 78, 274.

44) Tobian, L. et al., Ann. intern. Med., 1962, 57, 382.

45) Davis, J.O. et al., J. clin Inivest., 1962, 41, 378.

46) Gann, D.S. et al., J. Lab. clin. Med., 1962, 60, 877. 


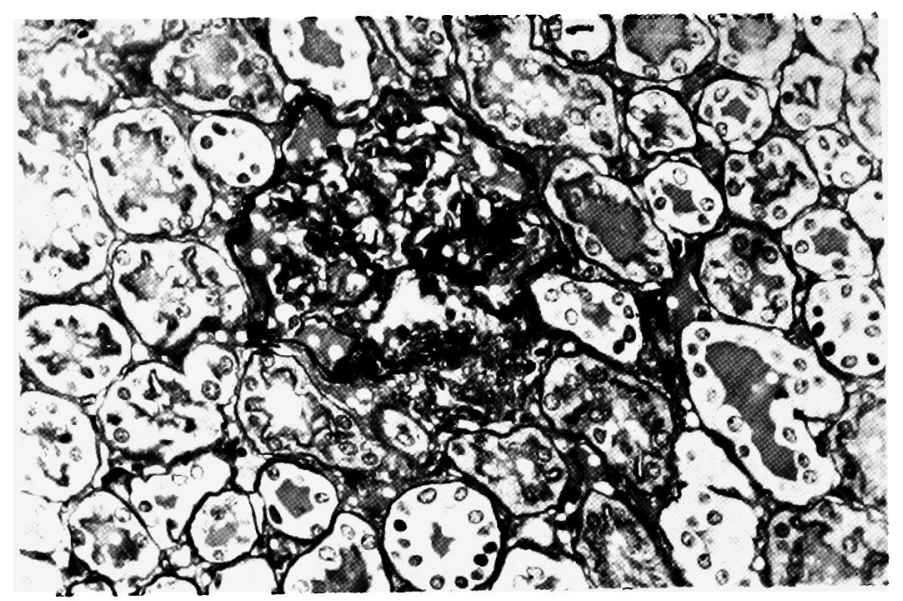

Fig. 5. Hypertension due to right renal artery stenosis. 13-year-old female. Marked hyperplasia of $\mathrm{JG}$ cells. PAS stain. $\times 200$.

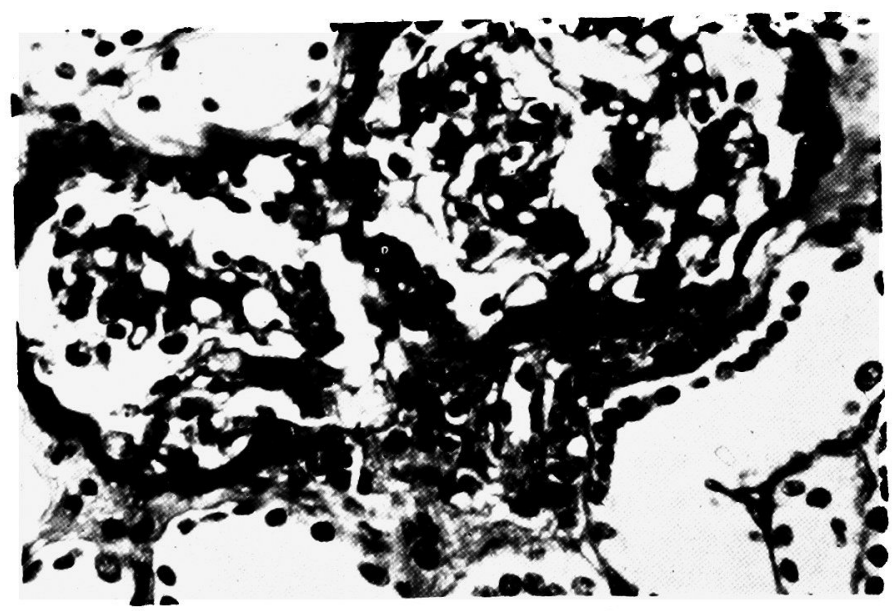

Fig. 6. Essential hypertension. 39-year-old male. Hyperplasia of JG cells. PAS stain. $\times 400$. 


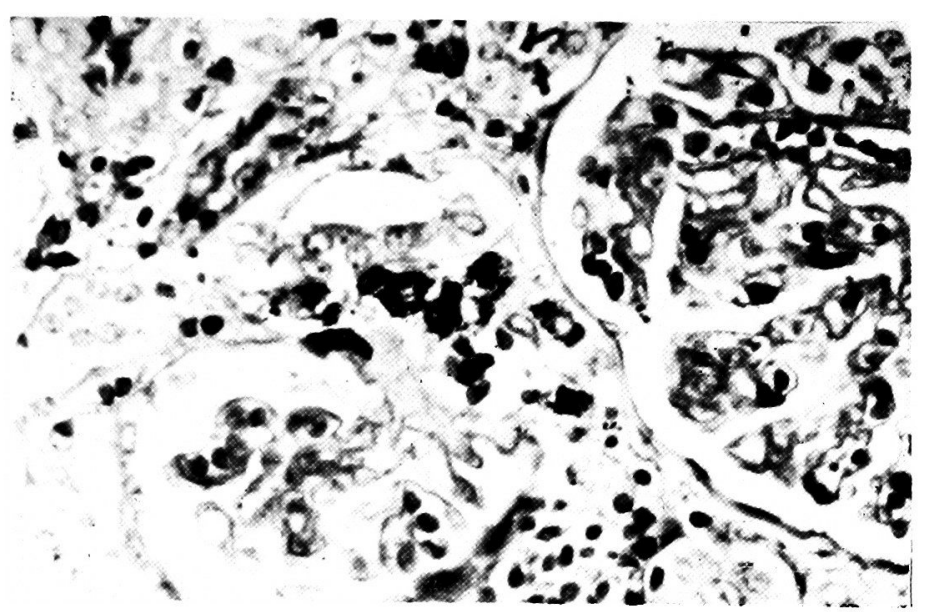

Fig. 7. Malignant hypertension. 52-year-old male. Hypergranularity of JG cells. Bowie stain. $\times 400$.

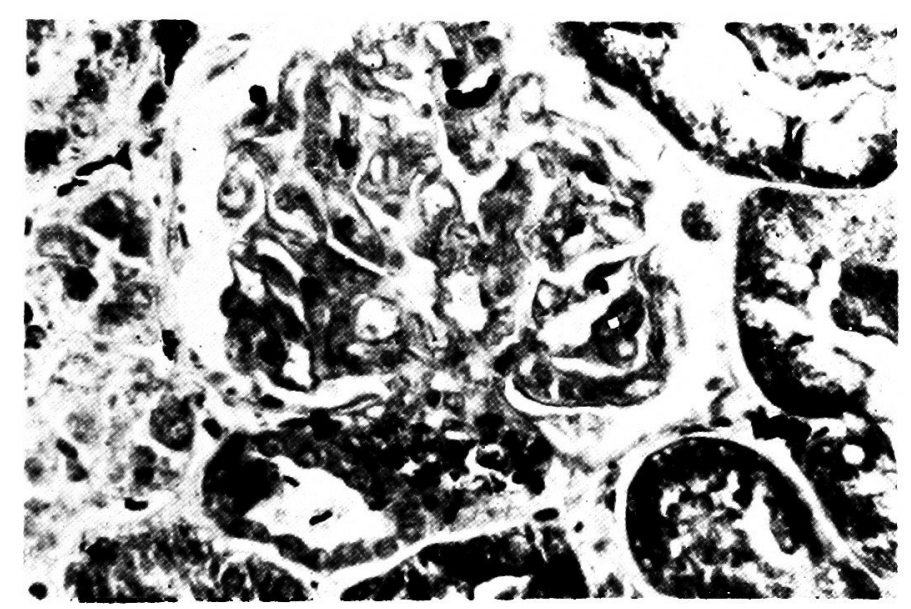

Fig. 8. Chronic hepatitis. 41-year-old male. Hypergranular juxtaglomerular cells. Bowie stain. $\times 400$. 


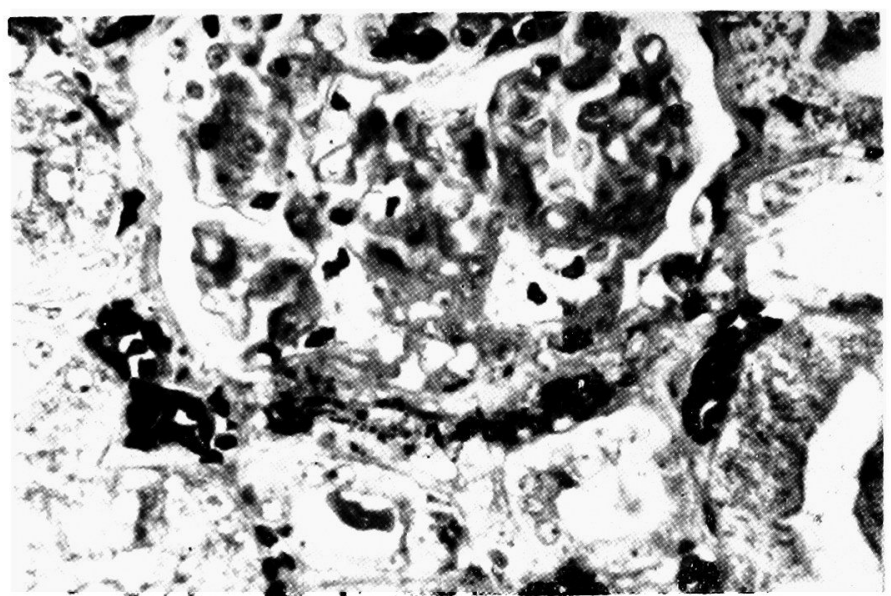

Fig. 9. Liver cirrhosis. 44-year-old male. Marked hypergranularity of JG cells. Bowie stain. $\times \mathbf{4 0 0}$.

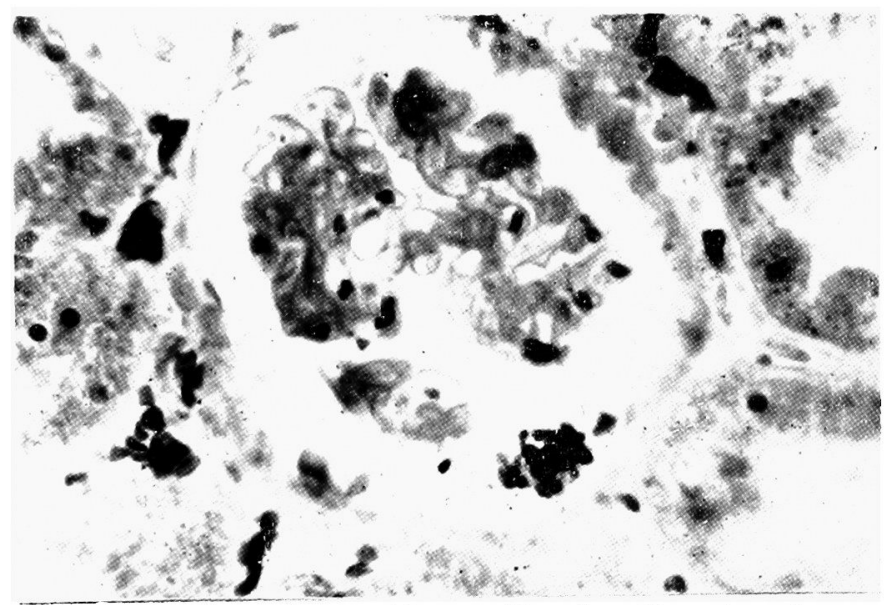

Fig. 10. Budd-Chiari's syndrome. 30-year-old male. Clumping of granules of JG cells. Bowie stain. $\times 400$. 